\title{
Irradiation free conditioning regimen is associated with high relapse rate in Egyptian patients with acute lymphoblastic leukemia following allogeneic hematopoietic stem cell transplantation
}

\author{
Mona Mahrous Abdelaty ${ }^{1 *}$ (D) Amr Gawaly ${ }^{1}$, Gamal M. Fathy², Ibrahim Kabbash³ and Atef Taha ${ }^{1}$
}

\begin{abstract}
Background: Allogeneic hematopoietic stem cell transplantation (Allo-HSCT) is a curative treatment for adult patients with acute lymphoblastic leukemia (ALL). Cyclophosphamide plus total body irradiation (TBI/Cy) or plus busulfan (Bu/Cy) is a widely used pre-transplant conditioning regimen for ALL. We retrospectively compared the overall survival (OS), disease-free survival (DFS), and other transplant outcomes of allo-HSCT in 119 adult patients with ALL who received an HLA-matched sibling allo-HSCT using TBI-based versus non-TBI-based conditioning regimens. Patients were divided into two groups by their conditioning regimen: TBI/Cy or Bu/Cy.

Results: Median OS was 11 months in the TBI/Cy group and 6.2 months in the Bu/Cy group. Median DFS was 11.1 months in the TBI group versus 6.8 months in the Bu group, without a statistically significant difference. A higher risk of relapse was observed with the Bu/Cy regimen (HR 2.709, CI 95\% 1.106 to 6.638, $p=0.029$ ). Patients who received a transplant in $\geq$ CR2 were associated with poor DFS.

Conclusion: Despite the high relapse rate in the non-TBI regimen (Bu/Cy), both regimens had no statistically significant differences in OS, DFS, and NRM. Additional prospective studies are indeed warranted to evaluate the long-term outcomes of radiation-free regimens, including oral and intravenous busulfan, and compare these regimens with $\mathrm{TBI}$-based ones.
\end{abstract}

Keywords: Allogeneic hematopoietic stem cell transplantation, Acute lymphoblastic leukemia, Conditioning, Total body irradiation, Busulfan

\section{Background}

ALL generally has an excellent prognosis in children with promising chemotherapy regimens [1]. In contrast, it is still challenging in adults as it is associated with poor survival outcomes and high relapse rates when treated with chemotherapy alone. Allo-HSCT is generally considered a

\footnotetext{
* Correspondence: drmona70@yahoo.com

${ }^{1}$ Internal Medicine Department, Hematology/Bone marrow transplantation

unit, Tanta University, Tanta, Algharbia, Egypt

Full list of author information is available at the end of the article
}

lifesaving option that is able to consolidate remission resulting in long-term DFS is adults [2].

Combinations of cyclophosphamide with either TBI or busulfan are the most commonly used myeloablative conditioning regimens (MAC) for allo-HSCT in adult ALL [3]. TBI has dual immunosuppressive and antileukemic properties with the ability to reach the hidden sites. It has expected better survival outcomes without an increase in relapse or transplant-related mortality (TRM). Unfortunately, at higher doses, TBI is associated with a potential risk of early and late complications [4]. 
Although busulfan-containing regimens can produce comparable outcomes with lower TRM, the oral form has wide variability in the absorption and metabolism. Also, high relapse rates have been observed with low levels of busulfan, while many risks including venoocclusive disease (VOD) have been related to higher levels [5].

Many studies have been carried out to evaluate the effect of different regimens on transplant outcomes, but the ideal conditioning regimen for adult ALL patients remains unknown [3]. This retrospective study aims to compare transplant outcomes in ALL patients using the $\mathrm{TBI} / \mathrm{Cy}$ and oral $\mathrm{Bu} / \mathrm{Cy}$ as $\mathrm{MAC}$ regimens.

\section{Methods}

A retrospective cohort study was done on data obtained from a tertiary center's bone marrow transplantation unit registry. The medical files of adult patients with ALL who received a transplant during the period 2000 to 2016 were reviewed. Patients aged 19 years or above at the time of first allo-HSCT from an HLA-matched sibling donor using $\mathrm{TBI} / \mathrm{Cy}$ or $\mathrm{Bu} / \mathrm{Cy}$ as a $\mathrm{MAC}$ regimen were included, either in first complete remission (CR1), CR2, or beyond. All patients had adequate performance scale and negative serology for the hepatitis B virus and the human immune deficiency virus (HIV).

Patients aged 60 years or above and those who received syngeneic or haploidentical allo-HSCT were excluded.

Detailed history has been reviewed, including data about age, sex, time from diagnosis to transplantation, Philadelphia chromosome, and disease status at transplantation time, associated comorbidities, viral status, donor type, stem cell source, CD34 cell dose, graft versus host disease (GVHD) prophylaxis, and transfusion requirements. Allo-HSCT outcome was assessed with the following parameters: time to engraftment, acute and chronic GVHD, incidence and severity of infections, and conditioning regimen-related toxicities. Survival outcomes included OS, DFS, NRM, and relapse.

\section{Conditioning regimens}

Patients included in our study were divided into two groups based on their conditioning regimens:

Group 1 included ALL patients who received allo HSCT from 2000 to 2015 and received TBI/Cy. The TBI dose was 12 Gy fractionated over 5 days (from day -10 to day -6). Cy was administrated as $30 \mathrm{mg} /$ day (from day -5 to day -2 of the stem cell infusion).

Group 2 included ALL patients who received allo HSCT from 2000 to 2016 and received $\mathrm{Bu} / \mathrm{Cy}$. The dose of oral busulfan was $16 \mathrm{mg} / \mathrm{kg}$ total dose over 4 days to be given as $4 \mathrm{mg} /$ day orally. The Cy dosage over 4 days was $120 \mathrm{mg} / \mathrm{kg}$ IV to be given as $30 \mathrm{mg} /$ day.

\section{GVHD prophylaxis}

All patients received prophylaxis for GVHD using methotrexate (MTX) and cyclosporine (CSA). MTX dose was $15 \mathrm{mg} / \mathrm{m}^{2}$ IV given on day +1 then changed to $10 \mathrm{mg} / \mathrm{m}^{2}$ on days $+3,+6$, and +11 , as well as folinic acid rescue $15 \mathrm{mg} / \mathrm{m}^{2}$ IV TDS for just $24 \mathrm{~h}$ on the day after MTX injection. MTX was monitored by the degree of mucositis and bilirubin level with the appropriate drug titration. CSA was administered in two divided doses from day -1 at a dose of $3 \mathrm{mg} / \mathrm{kg} /$ day IV that was replaced by an oral form once tolerated. The dose was modified to reach a therapeutic plasma CSA level of $200-250 \mathrm{mg} / \mathrm{ml}$. Renal functions and electrolytes were also monitored with drug titration accordingly.

\section{Supportive care}

Gastric protection by pantoprazole, antiemetics, using ondansetron were initiated at the start of the conditioning regimens and maximized as needed. All patients were given uromitexan guard against cyclophosphamideinduced hemorrhagic cystitis. Seizure prophylaxis by phenytoin was given before and during the administration of busulfan. Local mouth care and prophylaxis against bacterial, fungal, and viral infections were also given to all patients. Pneumocystis Jirovecii infection prophylaxis was done by trimethoprim-sulfamethoxazole (stopped in day -2 and re-initiated after engraftment). Preemptive treatment for cytomegalovirus (CMV) reactivation was given according to close molecular monitoring. Supportive irradiated blood products were administrated when needed; whole blood and granulocyte colony-stimulating growth factors (G-CSF) were received in some patients until neutrophil recovery.

\section{Study endpoints and operational definitions}

The primary endpoints were OS and DFS. OS was defined as time to death or last contact for survivors. DFS was identified as a time to treatment failure (relapse or death); for survivors, it was considered as the last contact in remission. The secondary endpoints were relapse and NRM. Relapse was considered as the recurrent appearance of hematological disease. We define NRM as a death in remission.

Engraftment was identified as the first of three consecutive days with an absolute count of neutrophils $>500 / \mu \mathrm{L}$ and platelets $>20,000 / \mu \mathrm{L}$ (unsupported) [6]. The diagnosis and grading of acute and chronic GVHD were based on the established criteria $[7,8]$. VOD diagnosis was based on the Baltimore clinical criteria [9]. Mucositis was identified and graded according to the National Cancer Institute (NCI-CTC) criteria [10], and grade 1 was considered as mild, grade 2 as moderate, and grades 3 and 4 as severe mucositis. Renal complications in our study were defined when serum creatinine was $\geq$ 
$2 \mathrm{mg} / \mathrm{dl}$ and/or requiring CSA cessation. CMV infection or reactivation was diagnosed when 2 consecutive titres of CMV DNA are above 500 copies $/ \mathrm{mL}$ in the presence of GVHD or above 1000 copies/mL in the absence of GVHD.

\section{Statistical analysis}

The collected data were organized, tabulated, and statistically analyzed by SPSS version 24 (Statistical Package for Social Studies) created by IBM, Illinois, Chicago, USA. For numerical values, the range, mean, and standard deviations were calculated. The differences between mean values were tested using $(t)$ test while the MannWhitney test $(Z)$ was used for other variables where data were not normally distributed. For categorical variables, the number and percentage were calculated, and differences between subcategories were tested using the chisquare test. When chi-square was not appropriate, Fisher and Monte Carlo exact tests were used as appropriate.

Table 1 Baseline characteristics of the study population

\begin{tabular}{|c|c|c|c|}
\hline Variable & $\begin{array}{l}\mathrm{TBI} / \mathrm{Cy} \\
(n=78)\end{array}$ & $\begin{array}{l}\mathrm{Bu} / \mathrm{Cy} \\
(n=41)\end{array}$ & $\begin{array}{l}p \\
\text { value }\end{array}$ \\
\hline${ }^{*}$ Age (years) & $\begin{array}{l}27.64 \pm 7.67 \\
(19-49)\end{array}$ & $\begin{array}{l}27.46 \pm 7.00 \\
(19-41)\end{array}$ & 0.902 \\
\hline \multicolumn{4}{|l|}{ Recipient sex } \\
\hline $\begin{array}{l}\text { Males } \\
\text { Females }\end{array}$ & $\begin{array}{l}56(71.8) \\
22(28.2)\end{array}$ & $\begin{array}{l}30(73.2) \\
11(26.8)\end{array}$ & 0.873 \\
\hline \multicolumn{4}{|l|}{ Immunophenotype } \\
\hline $\begin{array}{l}\mathrm{B} \\
\mathrm{T}\end{array}$ & $\begin{array}{l}52(66.7) \\
26(33.3)\end{array}$ & $\begin{array}{l}27(65.9) \\
14(34.1)\end{array}$ & 0.929 \\
\hline \multicolumn{4}{|l|}{ Performance status } \\
\hline $\begin{array}{l}0-1 \\
2\end{array}$ & $\begin{array}{l}75(96.2) \\
3(3.8)\end{array}$ & $\begin{array}{l}38(92.7) \\
3(7.3)\end{array}$ & 0.339 \\
\hline \multicolumn{4}{|l|}{ Ph chromosome status } \\
\hline $\begin{array}{l}\text { Negative } \\
\text { Positive }\end{array}$ & $\begin{array}{l}60(76.9) \\
18(23.1)\end{array}$ & $\begin{array}{l}32(78) \\
9(22)\end{array}$ & 0.889 \\
\hline \multicolumn{4}{|l|}{ Disease status at transplant } \\
\hline $\begin{array}{l}\text { CR } 1 \\
\geq \text { CR } 2\end{array}$ & $\begin{array}{l}40(51.3) \\
38(48.6)\end{array}$ & $\begin{array}{l}16(39) \\
25(61)\end{array}$ & 0.203 \\
\hline \multicolumn{4}{|l|}{ Pre-transplant Comorbidities } \\
\hline $\begin{array}{l}\text { No } \\
\text { Yes }\end{array}$ & $\begin{array}{l}76(85.9) \\
11(14.1)\end{array}$ & $\begin{array}{l}37(90.2) \\
3(9.8)\end{array}$ & 0.497 \\
\hline \multicolumn{4}{|l|}{ Donor sex } \\
\hline $\begin{array}{l}\text { Females } \\
\text { Males }\end{array}$ & $\begin{array}{l}33(42.3) \\
45(57.7)\end{array}$ & $\begin{array}{l}22(53.7) \\
19(64.3)\end{array}$ & 0.238 \\
\hline \multicolumn{4}{|l|}{$\begin{array}{l}\text { Donor/recipient CMV } \\
\text { seropositivity }\end{array}$} \\
\hline $\begin{array}{l}\text { Mismatched } \\
\text { Matched }\end{array}$ & $\begin{array}{l}7(9) \\
71(91)\end{array}$ & $\begin{array}{l}2(4.9) \\
39(95.1)\end{array}$ & 0.717 \\
\hline $\begin{array}{l}\text { *Diagnosis to transplant lag } \\
\text { period (month) }\end{array}$ & $\begin{array}{l}16.25 \\
(14-137.3)\end{array}$ & $\begin{array}{l}13.5 \\
(4.9-73.2)\end{array}$ & 0.114 \\
\hline
\end{tabular}

"Values are expressed as mean (range) and $n(\%)$
Table 2 Transplant outcomes

\begin{tabular}{llll}
\hline Variables & TBI/Cy $(n=78)$ & Bu/Cy $(n=41)$ & $p$ value \\
\hline Neutrophil engraftment(days) & $17(9-35)$ & $14(10-24)$ & 0.002 \\
Platelet engraftment (days) & $15(8-47)$ & $14(7-45)$ & 0.017 \\
Acute GVHD & & & 0.723 \\
$\quad$ Negative & $52(66.7)$ & $26(63.4)$ & \\
$\quad$ Positive & $26(33.3)$ & $15(36.6)$ & \\
Chronic GVHD & & & 0.106 \\
$\quad$ Negative & $54(69.2)$ & $34(82.9)$ & \\
$\quad$ Positive & $24(30.8)$ & $7(17.1)$ & \\
Relapse after transplant & & & \\
$\quad$ & & & \\
$\quad$ No & $69(88.5)$ & $30(73.2)$ & \\
$\quad$ Yes & $9(11.5)$ & $11(26.8)$ & \\
NRM & & & \\
$\quad$ & & \\
$\quad$ No & & & \\
$\quad$ Yes & $38(61.5)$ & $21(51.2)$ & \\
Val & $30(38.5)$ & $20(48.8)$ &
\end{tabular}

Values are expressed as median (range) and $n$ (\%)

For risk estimation, odds ratio was calculated and its 95\% confidence interval. For calculation of the hazard ratio and its $95 \%$ confidence interval for the independent effect of each predictor on a certain outcome to occur during the survival period of studied patients, Cox regression was performed. The level of significance was adopted at $p<0.05$.

Table 3 Multivariate analysis of non-relapse mortality, relapse, and engraftment

\begin{tabular}{|c|c|c|}
\hline Endpoints of the study & HR $(95 \% \mathrm{Cl})$ & $P$ \\
\hline \multicolumn{3}{|l|}{ NRM } \\
\hline \multicolumn{3}{|l|}{ Variables } \\
\hline Conditioning & $0.692(0.310-1.545)$ & 0.369 \\
\hline Age of recipient & $1.019(0.975-1.065)$ & 0.396 \\
\hline Disease status at BMT & $1.639(0.775-3.469)$ & 0.196 \\
\hline Ph chromosome status & 0.808(0.329-1.984) & 0.641 \\
\hline CD34 dose & $1.008(0.917-1.108)$ & 0.873 \\
\hline Comorbidities & $1.380(0.512-3.721)$ & 0.524 \\
\hline Diagnosis to transplant lag period & 1.005(0.989-1.023) & 0.531 \\
\hline \multicolumn{3}{|l|}{ Relapse } \\
\hline \multicolumn{3}{|l|}{ Variables } \\
\hline Conditioning (TBI/Cy versus Bu/Cy) & $2.709(1.106-6.638)$ & 0.029 \\
\hline Age of recipient & $0.977(0.914-1.045)$ & 0.500 \\
\hline Philadelphia chromosome status & $0.1321(0.437-3.995)$ & 0.622 \\
\hline \multicolumn{3}{|l|}{ Engraftment } \\
\hline \multicolumn{3}{|l|}{ Variables } \\
\hline Conditioning (TBI/Cy versus Bu/Cy) & $1.229(0.809-1.868)$ & 0.333 \\
\hline Disease status at BMT & $1.085(0.774-1.521)$ & 0.635 \\
\hline CD34 dose & $0.999(0.942-1.059)$ & 0.970 \\
\hline
\end{tabular}

$H R$ hazard ratio, $\mathrm{Cl}$ confidence interval 


\section{Results}

A total of 119 adult patients with ALL received alloHSCT from HLA-matched sibling donors from January 2000 to December 2016. Seventy-eight patients were transplanted using $\mathrm{TBI} / \mathrm{Cy}$, and forty-one patients were transplanted using oral $\mathrm{Bu} / \mathrm{Cy}$.

\section{Baseline characteristics of study population}

The baseline characteristics of the seventy-eight patients received $\mathrm{TBI} / \mathrm{Cy}$ and the forty-one patients received $\mathrm{Bu} /$ Cy regimens are described in Table 1 . The age ranged from $19-49$ to $19-41$ years in the TBI/Cy and the Bu/Cy groups, respectively, with a mean age at transplant of $27.64 \pm 7.67$ in the TBI/Cy and 27.46 \pm 7.00 in the $\mathrm{Bu} / \mathrm{Cy}$ group. In the $\mathrm{TBI} / \mathrm{Cy}$ group, $56(71.8 \%)$ patients were males, and $22(28.2 \%)$ were females, while in the $\mathrm{Bu} / \mathrm{Cy}$ group, $73.2 \%$ of patients were males. B-ALL was the main subtype in both groups. Most of the patients in both groups had adequate performance. Philadelphia chromosome was positive in 18 (23.1\%) patients in the TBI /Cy group and 9 (22\%) patients in the $\mathrm{Bu} / \mathrm{Cy}$ group.

At the time of transplant, $51.3 \%$ of patients were in $\mathrm{CR} 1$ in the $\mathrm{TBI} / \mathrm{Cy}$ versus $39 \%$ in the $\mathrm{Bu} / \mathrm{Cy}$ group. Among the 119 patients, only 14 patients were reported to have pre-transplant comorbidities which included diabetes, hypertension, and chronic liver disease. Female donors represented (42.3\%) in the TBI group and $(53.7 \%)$ in the $\mathrm{Bu} / \mathrm{Cy}$ group. Female donors to male recipients were found in 24 patients in the TBI/Cy group and 16 patients in the $\mathrm{Bu} / \mathrm{Cy}$ group. Seven patients (9\%) in the TBI group had mismatched CMV donor versus 2 patients (4.9\%) in the $\mathrm{Bu}$ group. The time from diagnosis to transplantation was ranged from 14 to 137.3 months in the TBI group and (4.9-73.2) months in the Bu/Cy group. All these differences were found to be statistically not significant.

\section{Engraftment and GVHD}

One hundred and eleven (93.3\%) achieved engraftment ,and only eight patients $(6.7 \%)$ had primary graft failure. Significant faster engraftment was observed in the $\mathrm{Bu} / \mathrm{Cy}$ group, a median time to neutrophil engraftment was 17 days (range 9-35) in the TBI /Cy group and 14 days (range10-24) in the $\mathrm{Bu} / \mathrm{Cy}$ group, while the median time for platelet engraftment was 15 and 14 days in the TBI and the $\mathrm{Bu}$ groups, respectively (Table 2 ). However, no significant difference could be detected between the two groups in the term of engraftment by the multivariate analysis (Table 3). The incidence of acute and GVHD was similar in both groups (Table 2).

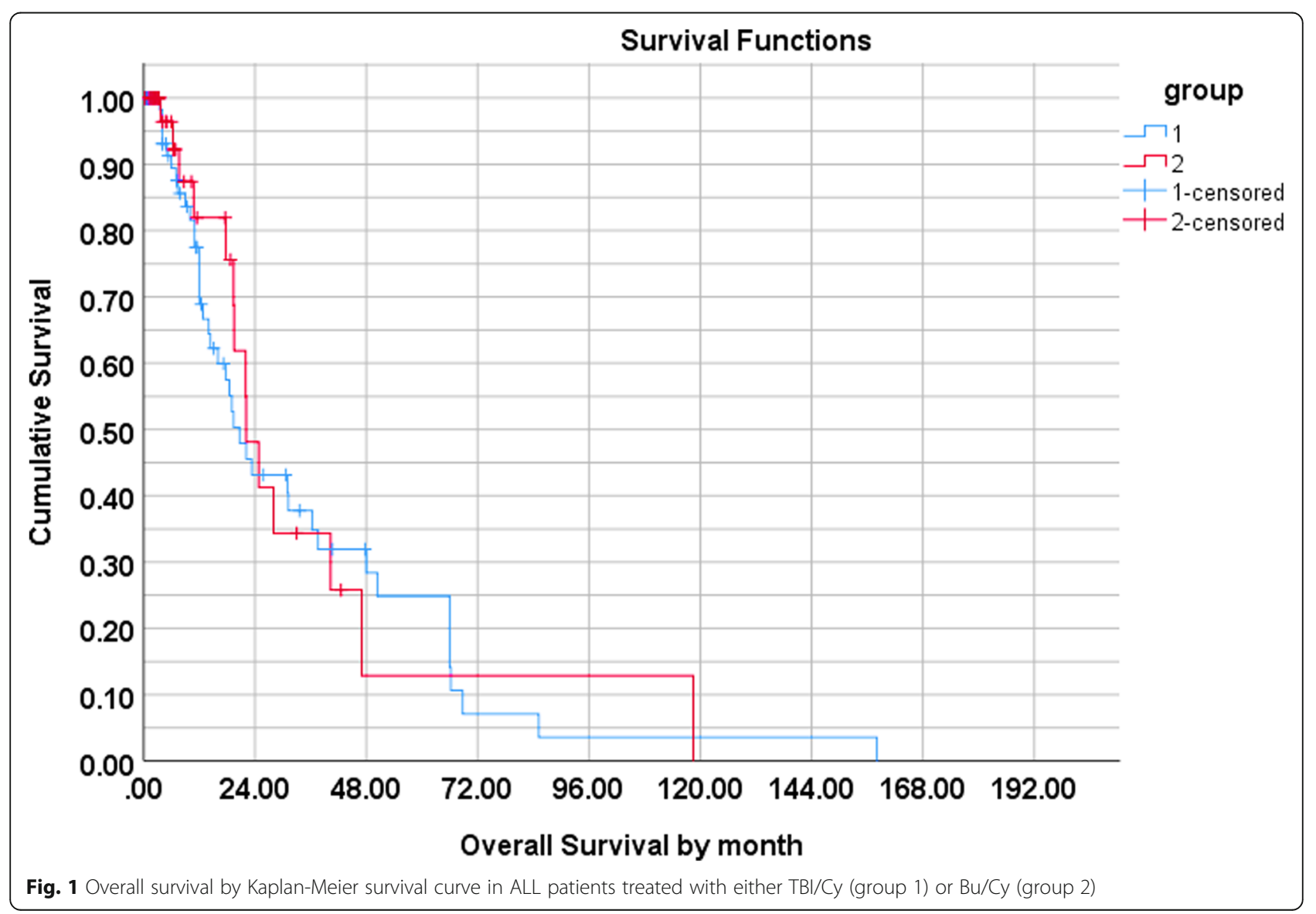




\section{Relapse and NRM}

Regarding relapse, $16.8 \%(n, 119)$ of patients developed relapse after transplant. A significantly high relapse rate was observed in the $\mathrm{Bu} / \mathrm{Cy}$ group (26.8\% versus $11.5 \%$ in the $\mathrm{TBI} / \mathrm{Cy}$ group) (Table 2). The $\mathrm{Bu} / \mathrm{Cy}$ regimen was identified as an independent risk factor for relapse by the multivariate analysis (Table 3). The incidence of NRM was similar in the two groups, which was proved by the univariate and multivariate analysis (Tables 2 and 3 ). The most common cause of NRM in the TBI group was sepsis (36.8\%), while respiratory failure was the major cause in the Bu group (22.2\%).

\section{DFS and OS}

The survival rate was $51.3 \%$ and $34.1 \%$ in the TBI/Cy and $\mathrm{Bu} / \mathrm{Cy}$ group, respectively. The follow-up period ranged from (0.3-158) months in the TBI group with a median OS of 11 months, while it ranged from $0.3-$ 118.5 months in the $\mathrm{Bu}$ group with a median OS of 6.2 months. The median DFS was 11.1 versus 6.8 months for TBI and $\mathrm{Bu}$ groups, respectively. The estimated 2-year OS was $42 \%$ in the TBI group and $44 \%$ in the $\mathrm{Bu}$ group. The estimated 2-year DFS was $80 \%$ in the TBI group compared to $55 \%$ in the $\mathrm{Bu}$ group.
All these differences were statistically non-significant (Figs. 1 and 2).

No independent risk factors for low OS were detected by the multivariate analysis. Disease status at transplant was the only independent risk factor for poor DFS in both groups, and patients received a transplant at CR2 or beyond were associated with poor DFS, HR, 3.670 (CI $95 \% 1.500-8.978$ and $p$ 0.004). However, the disease status at transplant had no independent effect on relapse risk, OR, 0.420; CI 95\% 0.149-1.182 (Tables 4 and 5).

\section{Conditioning regimen related toxicity}

Severe mucositis was significantly higher in the TBI/Cy group (37.2\% versus $9.8 \%$ in the $\mathrm{Bu} / \mathrm{Cy}$ group). A significantly higher incidence of bacterial infections was found in the TBI group (43.6 versus $24.5 \%$ in the $\mathrm{Bu} / \mathrm{Cy}$ group). Both groups had a similar incidence of VOD and hemorrhagic complications. Although eight patients (17.8\%) had CMV reactivation after the transplant, this could not be proven when tested by multivariate analysis. In the TBI/Cy group, three patients developed idiopathic pneumonitis, and five patients developed osteoporosis as a complication of TBI regimen related toxicity (Table 6).

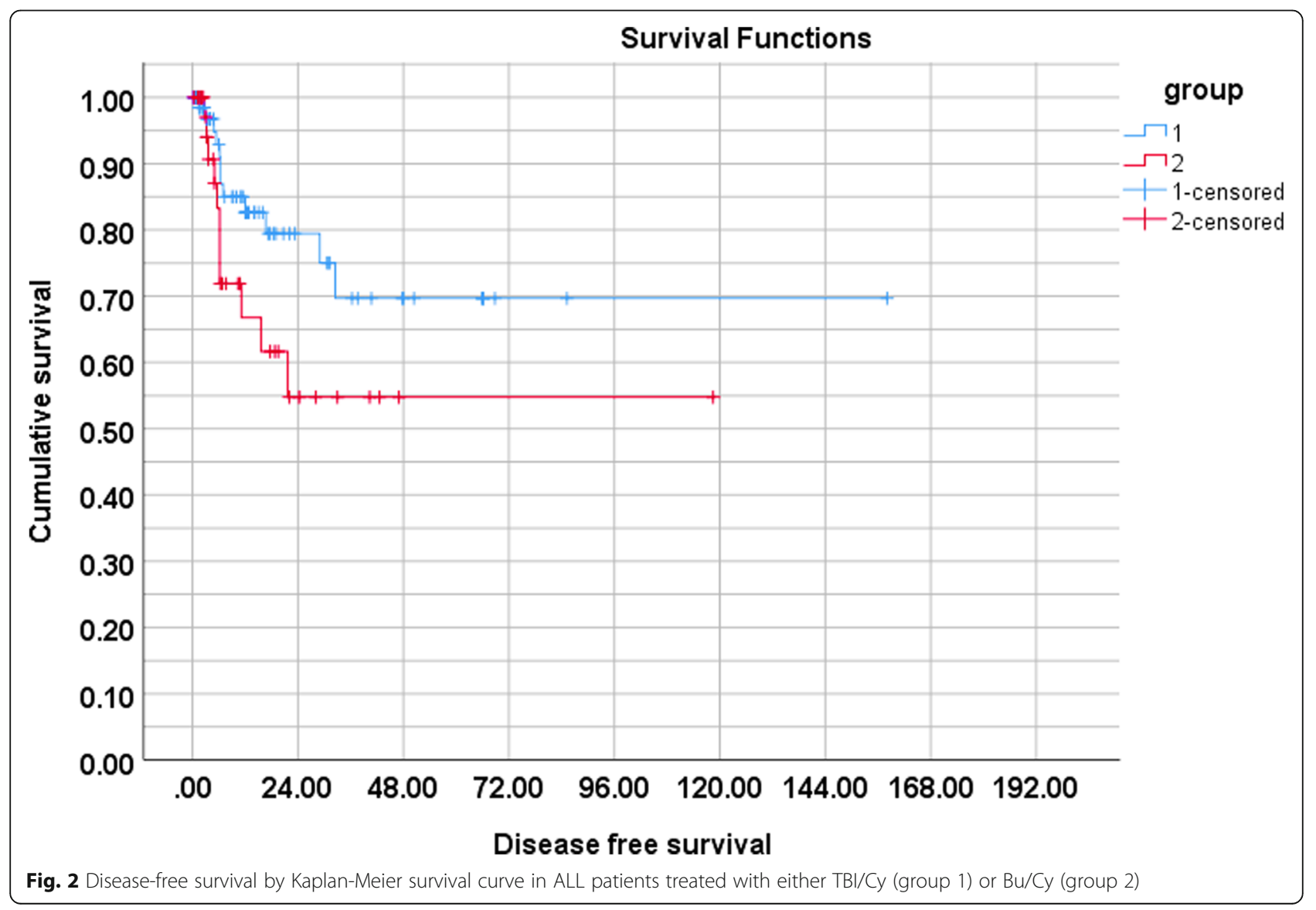


Table 4 Multivariate analysis of overall survival and disease-free survival

\begin{tabular}{|c|c|c|}
\hline Endpoints of the study & $\mathrm{HR}(95 \% \mathrm{Cl})$ & $P$ \\
\hline \multicolumn{3}{|l|}{ DFS } \\
\hline \multicolumn{3}{|l|}{ Variables } \\
\hline Type of conditioning & $1.391(0.537-3.600)$ & 0.497 \\
\hline Age of recipient & $0.982(0.898-1.073)$ & 0.685 \\
\hline Sex of recipient & $0.381(0.115-1.263)$ & 0.115 \\
\hline Disease status at BMT(CR1 vs $\geq$ CR2) & $3.670(1.500-8.978)$ & 0.004 \\
\hline Ph chromosome status & $1.303(0.387-4.379)$ & 0.669 \\
\hline Diagnosis to transplant lag & $0.961(0.902-1.002)$ & 0.064 \\
\hline \multicolumn{3}{|l|}{ OS } \\
\hline \multicolumn{3}{|l|}{ Variables } \\
\hline Conditioning (TBI/Cy vs Bu/cy) & $0.764(0.371-1.573)$ & 0.466 \\
\hline Age of recipient ( $\leq 30$ vs $\geq 30$ ) & $1.014(0.974-1.056)$ & 0.489 \\
\hline Sex of recipient (Female vs male) & $1.461(0.709-3.013)$ & 0.304 \\
\hline Disease status at BMT(CR1 vs $\geq$ CR2) & $1.660(0.813-3.390)$ & 0.164 \\
\hline $\begin{array}{l}\text { Philadelphia chromosome status } \\
\text { (Ph-ve vs } \mathrm{Ph}+\text { ve) }\end{array}$ & $0.877(0.400-1.922)$ & 0.743 \\
\hline Diagnosis to transplant lag & $1.000(0.985-1.014)$ & 0.946 \\
\hline
\end{tabular}

\section{Discussion}

TBI-based regimens are widely used for ALL patients and are showing excellent outcomes without increasing the relapse rate. However, to avoid the wide range of long and short-term complications of TBI, the alternative radiation-free regimens based on $\mathrm{Bu}$ were introduced with the ability to produce comparable clinical results with lower transplant-related mortality and morbidity [3]. In the present study, we compared the clinical outcomes in two groups of ALL patients who underwent allo-HSCT using TBI/Cy conditioning versus a radiation-free regimen of oral $\mathrm{Bu}$ plus $\mathrm{Cy}$.

Similar OS, DFS, and NRM were observed in both treatment groups; using multivariate analysis, the conditioning regimen was not an independent risk of OS, DFS, or NRM. However, patients who received a transplant in $\geq$ CR2 had lower DFS in both groups. Relapse remains the leading reason for treatment failure, and a common cause of death in ALL patients received alloHSCT. Using TBI is associated with lower relapse rates in many patients [11]. In this study, using the $\mathrm{Bu} / \mathrm{Cy}$ regimen was accompanied by a significantly higher relapse rate that was confirmed in the multivariate analysis.

Recent research by Wang and colleagues who carried a retrospective analysis on 224 adult patients with ALL in Taiwan noted similar results; patients who received $\mathrm{Bu} / \mathrm{Cy}$ or TBI conditioning had similar OS, DFS, and NRM. Disease status before HSCT was the only risk factor of survival in his patients with poor DFS in patients
Table 5 Analysis of risk factors of relapse among study participants

\begin{tabular}{|c|c|c|c|c|c|c|}
\hline \multirow[t]{2}{*}{ Variables } & \multicolumn{2}{|c|}{ Relapsed } & \multicolumn{2}{|c|}{ Non relapsed } & \multirow[t]{2}{*}{ OR } & \multirow[t]{2}{*}{$95 \% \mathrm{Cl}$} \\
\hline & $n$ & $\%$ & $n$ & $\%$ & & \\
\hline \multicolumn{7}{|c|}{ Treatment group } \\
\hline $\mathrm{TBI} / \mathrm{Cy}$ & 9 & 11.5 & 69 & 88.5 & 0.356 & $0.134-0.948$ \\
\hline $\mathrm{Bu} / \mathrm{Cy}$ & 11 & 26.8 & 30 & 73.2 & & \\
\hline \multicolumn{7}{|c|}{ Donor/recipient sex matching } \\
\hline Mismatch & 15 & 20.5 & 58 & 79.5 & 2.121 & $0.714-6.297$ \\
\hline Matching & 5 & 10.9 & 41 & 89.1 & & \\
\hline \multicolumn{7}{|l|}{ Age in years } \\
\hline$<30$ & 12 & 16.4 & 61 & 83.6 & 0.934 & $0.350-2.495$ \\
\hline$\geq 30$ & 8 & 17.4 & 38 & 82.6 & & \\
\hline \multicolumn{7}{|l|}{ Phenotype } \\
\hline B & 11 & 13.9 & 68 & 86.1 & 0.557 & $0.210-1.482$ \\
\hline $\mathrm{T}$ & 9 & 22.5 & 31 & 77.5 & & \\
\hline \multicolumn{7}{|c|}{ Philadelphia chromosome status } \\
\hline Negative & 15 & 16.3 & 77 & 83.7 & 0.857 & $0.280-2.621$ \\
\hline Positive & 5 & 18.5 & 22 & 81.5 & & \\
\hline \multicolumn{7}{|c|}{ Disease status at transplant } \\
\hline CR 1 & 6 & 10.7 & 50 & 89.3 & 0.420 & $0.149-1.182$ \\
\hline$\geq C R 2$ & 14 & 22.2 & 49 & 77.8 & & \\
\hline \multicolumn{7}{|l|}{ Recipient sex } \\
\hline Females & 12 & 14.0 & 74 & 86.0 & 0.507 & $0.186-1.382$ \\
\hline Males & 8 & 24.2 & 25 & 75.8 & & \\
\hline
\end{tabular}

OR Odds ratio, $\mathrm{Cl}$ Confidence interval

transplanted in $\geq$ CR2 [12]. Another recent study published by the Center of International Blood and Marrow Transplantation (CIBMTR) concluded that the $\mathrm{Bu} / \mathrm{Cy}$ patients had significantly more relapses than the TBI patients (HR, 1.46, 95\% CI 1.15 to $1.85, p=.002)$ [13], which was similar to our results. The advantage of TBI over busulfan in reducing post-transplant relapse was also confirmed in a large analysis by the European Society for Blood and Marrow Transplantation (EBMT) that reported a high rate of relapse in the $\mathrm{Bu} / \mathrm{Cy}$ group of ALL patients transplanted in CR1 [14].

Unlike our findings, the authors of a recent metaanalysis including over 800 ALL patients reported lower DFS, better NRM with the oral Bu/Cy regimens than the TBI ones, and a similar risk of relapse [15]. In the Japanese retrospective analysis by Mitsuhashi and colleagues [16], in addition to a large meta-analysis of fifteen nonrandomized comparative studies of 6280 patients [17], a lower NRM with TBI compared to oral $\mathrm{Bu} / \mathrm{Cy}$ conditioning was reported without a significant difference in the relapse risk between both regimens, which was against our findings. 
Table 6 Comparison between the studied groups according to regimen-related toxicity

\begin{tabular}{|c|c|c|c|}
\hline Variable & TBI/Cy $(n=78)$ & $\mathrm{Bu} / \mathrm{Cy}(n=41)$ & $p$ value \\
\hline Mucositis & & & 0.005 \\
\hline Negative & $27(34.6)$ & $16(39.0)$ & \\
\hline Mild & $12(15.4)$ & $8(19.5)$ & \\
\hline Moderate & $10(12.8)$ & $13(31.7)$ & \\
\hline Severe & $29(37.2)$ & $4(9.8)$ & \\
\hline Veno-occlusive disease & & & 0.691 \\
\hline Negative & $74(94.9)$ & $38(92.7)$ & \\
\hline Positive & $4(5.1)$ & $3(7.3)$ & \\
\hline Hemorrhagic cystitis & & & 0.100 \\
\hline Negative & $71(91.0)$ & $33(80.5)$ & \\
\hline Positive & $7(9.0)$ & $8(19.25)$ & \\
\hline Idiopathic pneumonitis & & & 0.278 \\
\hline Negative & $75(96.2)$ & $41(100.0)$ & \\
\hline Positive & $3(3.8)$ & $0(0.0)$ & \\
\hline Diffuse alveolar & & & 0.545 \\
\hline Negative & 76 (97.4) & $41(100.0)$ & \\
\hline Positive & $2(2.6)$ & $0(0.0)$ & \\
\hline Osteoporosis & & & 0.116 \\
\hline Negative & 73 (93.6) & $41(100.0)$ & \\
\hline Positive & $5(6.4)$ & $0(0.0)$ & \\
\hline Infections & & & 0.037 \\
\hline Negative & $40(51.2)$ & $29(70.7)$ & \\
\hline Bacterial & $34(43.6)$ & $10(24.5)$ & \\
\hline Fungal & $2(2.6)$ & $1(2.4)$ & \\
\hline Viral & $2(2.6)$ & $1(2.4)$ & \\
\hline CMV reactivation & & & 0.017 \\
\hline Negative & 73 (93.6) & $32(78.0)$ & \\
\hline Positive & $5(6.4)$ & $9(22.0)$ & \\
\hline
\end{tabular}

Variables are expressed as number and $\%$

A similar incidence of acute and chronic GVHD was observed among patients in both groups of the study, and this was similar to the findings published by Eroglu et al. [18].

For most MAC regimens including TBI, the incidence of severe mucositis ranged from 30 to $70 \%$, increasing the risk of febrile neutropenia, serious infections, and the need for parenteral nutrition or narcotic therapy for pain control [19]. In this study, we demonstrated a significantly higher incidence of severe mucositis and bacterial infections associated with the use of TBI.

Previous studies reported an increase in the risk of VOD with the oral busulfan due to unpredictable absorption, supporting the use of the intravenous form to decrease the risk of such a fatal complication [5, 20]. Although fatal VOD was present in three patients in the
$\mathrm{Bu} / \mathrm{Cy}$ group compared to one patient in the $\mathrm{TBI} / \mathrm{Cy}$ group, we could not find a significant impact of the conditioning regimen on the VOD risk in the multivariate analysis. Similarly, Sakellari et al. [21] found no significant difference in the VOD incidence among ALL patients who received $\mathrm{TBI}$ or $\mathrm{Bu}$-based conditioning regimens. In contrast, we disagreed with the findings of a retrospective study by Kalaycio et al. who noted a higher incidence of VOD in patients received oral busulfan compared to those in the TBI group [22].

It should be noted that our study did not provide data on the plasma level of oral busulfan due to it was unavailable in a standardized lab in our country during the study period; it is unknown to what degree the dose adjustment according to the oral busulfan plasma level may have contributed to our findings.

Among our study participants, sepsis was the main cause of death in the TBI/Cy group, followed by relapse and organ failure. While in the $\mathrm{Bu} / \mathrm{Cy}$ group, relapse was the leading cause of mortality followed by respiratory failure and sepsis. These findings were similar to a recent report from the CIBMTR [23].

\section{Conclusion}

The two regimens offer sufficient immunosuppression facilitating engraftment, without significant difference in OS or DFS. The $\mathrm{Bu} / \mathrm{Cy}$ regimen was associated with a higher risk of relapse compared to the TBI-based one. In this study, the TBI-based regimen appears to be slightly superior to the $\mathrm{Bu} / \mathrm{Cy}$ one in terms of low relapse rates. The variability in the absorption and metabolism of the oral busulfan formulation could be the cause of plasmalevel differences that can cause many conflicting results and toxicity with the two regimens.

\section{Study limitations}

We must address the limitations of this study. This is a retrospective study with a relatively small number of participants. It is also worth mentioning that the intravenous Bu could not be used due to unavailability in our country. Despite these limitations, we had a relatively homogenous group of patients with similar baseline characteristics who received transplants in a large transplantation center using the standard procedures and had the advantage of a long period of follow-up in most of the patients. Our data might provide the basis for further larger prospective studies aiming at optimizing the conditioning regimens in adult ALL.

\section{Abbreviations}

Allo-HSCT: Allogeneic hematopoietic stem cell transplantation; ALL: Acute lymphoblastic leukemia; CIBMTR: Center of international blood and marrow transplantation registry; DFS: Disease-free survival; EBMT: The European Society for Blood and Marrow Transplantation; GVHD: Graft versus host disease; G-CSF: Granulocyte colony-stimulating growth factors; 
MAC: Mayloablative conditioning; NRM: Non-relapse mortality; OS: Overall survival; VOD: Veno-occlusive disease

\section{Acknowledgements \\ Not applicable}

\section{Authors' contributions}

MMA and GMF contributed to the concept and data collection. IK analyzed and interpreted the patient data and had a major role in the revision of the manuscript. MMA wrote the manuscript. MMA, IK, AG, and AT shared in the revision of the article. All authors have read and approved the manuscript.

\section{Funding}

Not applicable.

\section{Availability of data and materials}

The datasets used and/or analyzed during the current study are available from the corresponding author on reasonable request. The baseline data that support the finding of this work were obtained from BMT unit registry of Nasser institute after permission.

\section{Ethics approval and consent to participate}

The study was conducted by the stipulations of the local ethical and scientific committee of Tanta University, Egypt. Ethics approval code number 31611. The files were retrieved after concealing the personal details of patients to keep the confidentiality of data.

\section{Consent for publication}

Not applicable.

\section{Competing interests}

The authors declare that they have no competing interests.

\section{Author details}

${ }^{1}$ Internal Medicine Department, Hematology/Bone marrow transplantation unit, Tanta University, Tanta, Algharbia, Egypt. ${ }^{2}$ Nasser Institute Hospital for Research and Treatment, Cairo, Egypt. ${ }^{3}$ Public Health and Community Medicine Department, Tanta University, Tanta, Egypt.

Received: 24 March 2020 Accepted: 19 May 2020

Published online: 15 June 2020

\section{References}

1. Hunger SP, Mullighan CG. Acute lymphoblastic leukemia in children. N Engl Med. 2015;373(16):1541-52

2. Thomas $X$, Le Jeune C. Current management of adult acute lymphoblastic Leukemia: Emerging insights and outstanding questions. EMJ Hematol. 2016:4(1):117-28.

3. Tracey J, Zhang MJ, Thiel E, Sobocinski KA, Eapen M. Transplantation conditioning regimens and outcomes after allogeneic hematopoietic cell transplantation in children and adolescents with acute lymphoblastic leukemia. Biol Blood Marrow Transplant. 2013 Feb 1;19(2):255-9.

4. Mori T, Aisa Y, Kato J, Yamane A, Nakazato T, Shigematsu N, et al. Safety and efficacy of total body irradiation, cyclophosphamide, and cytarabine as a conditioning regimen for allogeneic hematopoietic stem cell transplantation in patients with acute lymphoblastic leukemia. Am J Hematol. 2012 Apr;87(4):349-53.

5. Palmer J, McCune JS, Perales MA, Marks D, Bubalo J, Mohty M, et al. Personalizing busulfan-based conditioning: considerations from the American Society for Blood and MarrowTtransplantation Practice Guidelines Committee. Biol Blood Marrow Transplant. 2016;22(11):1915-25.

6. Ratajczak MZ, Suszynska M. Emerging strategies to enhance homing and engraftment of hematopoietic stem cells. Stem Cell Rev Rep. 2016;12(1):121-8.

7. Goyal RK, Voller D, Goyal M, Sankaranarayan K. Grading acute GVHD: getting it right every time! Biol Blood Marrow Transplant. 2015;21(2):S118.

8. Lee SJ. Classification systems for chronic graft-versus-host disease. Blood 2017;129(1):30-7.

9. Mohty M, Malard F, Abecassis M, Aerts E, Alaskar AS, Aljurf M, et al. Revised diagnosis and severity criteria for sinusoidal obstruction syndrome/venoocclusive disease in adult patients: a new classification from the European
Society for Blood and Marrow Transplantation. Bone Marrow Transplant. 2016:51(7):906-12.

10. US Department of Health and Human Services. Common terminology criteria for adverse events (CTCAE) version 4.0. National Institutes of Health, National Cancer Institute. 2009 May 28;4(03).

11. Chen R, Campbell $J$, Chen B. Prophylaxis and treatment of acute lymphoblastic leukemia relapse after allogeneic hematopoietic stem cell transplantation. OncoTargets Therapy. 2015;8:405-12.

12. Wang $\mathrm{YH}$, Ko BS, Liao XW, Yao M, Tang JL. Busulfan-containing conditioning regimens in allogeneic hematopoietic stem-cell transplantation for acute lymphoblastic leukemia: single tertiary center experience in Taiwan. Biol Blood Marrow Transplant. 2019;25(3):S188

13. Kebriaei $\mathrm{P}$, Anasetti $\mathrm{C}$, Zhang MJ, Wang HL, Aldoss I, de Lima M, et al. Intravenous busulfan compared with total body irradiation pretransplant conditioning for adults with acute lymphoblastic leukemia. Biol Blood Marrow Transplant. 2018;24(4):726-33.

14. Giebel $S$, Labopin $M$, Socié $G$, Beelen D, Browne $P$, Volin L, et al. Improving results of allogeneic hematopoietic cell transplantation for adults with acute lymphoblastic leukemia in first complete remission: an analysis from the Acute Leukemia Working Party of the European Society for Blood and Marrow Transplantation. Haematologica. 2017;102(1):139-49.

15. Shi-Xia X, Xian-Hua T, Hai-Qin X, Bo F, Xiang-Feng T. Total body irradiation plus cyclophosphamide versus busulphan with cyclophosphamide as conditioning regimen for patients with leukemia undergoing allogeneic stem cell transplantation: a meta-analysis. Leuk Lymphoma. 2010;51(1):50-60.

16. Mitsuhashi K, Kako S, Shigematsu A, Atsuta Y, Doki N, Fukuda T, et al. Comparison of cyclophosphamide combined with total body irradiation, oral busulfan, or intravenous busulfan for allogeneic hematopoietic cell transplantation in adults with acute lymphoblastic leukemia. Biol Blood Marrow Transplant. 2016:22(12):2194-200.

17. Gupta T, Kannan S, Dantkale V, Laskar S. Cyclophosphamide plus total body irradiation compared with busulfan plus cyclophosphamide as a conditioning regimen prior to hematopoietic stem cell transplantation in patients with leukemia: a systematic review and meta-analysis. Hematol Oncol Stem Cell Ther. 2011;4(1):17-29.

18. Eroglu C, Pala C, Kaynar L, Yaray K, Aksozen MT, Bankir M, et al. Comparison of total body irradiation plus cyclophosphamide with busulfan plus cyclophosphamide as conditioning regimens in patients with acute lymphoblastic leukemia undergoing allogeneic hematopoietic stem cell transplant. Leuk Lymphoma. 2013;54(11):2474-9.

19. Vasquenza K, Ruble K, Chen A, Billett C, Kozlowski L, Atwater S, Kost-Byerly S. Pain management for children during bone marrow and stem cell transplantation. Pain Manag Nurs. 2015;16(3):156-62.

20. Sobocinski KA, Thall PF, Bekele BN, Klein JP, Lennon S, Horowitz MM, et al. Matched pairs analysis of IV vs PO busulfan as a conditioning agent prior to transplantation. ASH Annual Meeting abstract. Blood. 2004;104(11):349.

21. Sakellari I, Gavriilaki E, Chatziioannou K, Papathanasiou M, Mallouri D, Batsis I, et al. Long-term outcomes of total body irradiation plus cyclophosphamide versus busulfan plus cyclophosphamide as conditioning regimen for acute lymphoblastic leukemia: a comparative study. Ann Hematol. 2018;97(10):1987-94.

22. Kalaycio M, Bolwell B, Rybicki L, Absi A, Andresen S, Pohlman B, et al. BU-vs TBI-based conditioning for adult patients with ALL. Bone Marrow Transplant. 2011:46(11):1413-7.

23. D'Souza A, Fretham C. Current uses and outcomes of hematopoietic cell transplantation (HCT): CIBMTR summary slides. Center for International Blood \& Marrow Transplant Research. https://www.cibmtr.Org/ ReferenceCenter/SlidesReports/SummarySlides/pages/index.aspx Updated June. 2018 Jun; 13.

\section{Publisher's Note}

Springer Nature remains neutral with regard to jurisdictional claims in published maps and institutional affiliations. 